\title{
Does a Deposit Insurance Scheme Induce Moral Hazard among Bankers? Evidence from an Experiment with Bankers
}

\author{
Gumilang Aryo Sabadewo," Bernardinus Maria Purwanto, and Rimawan Pradiptyo \\ Universitas Gadjah Mada
}

\begin{abstract}
The implementation of a deposit insurance scheme entails a trade-off. On the one hand, as shown in theoretical and empirical studies, a deposit insurance scheme reduces the likelihood of a bank run. On the other hand, a deposit insurance scheme induces moral hazard among bankers that may lead to bank failures. This study rigorously tests the effect of different deposit coverage limits and the implementation of a differential premium treatment on bankers' behaviours in the deposit and credit market using a laboratory experiment designed to involve real bankers as participants. This study found that the coverage of limit treatments does not have any effect on the deposit rate offer. Nevertheless, this study found that a high deposit coverage limit induces smaller banks to have a higher share of risky projects. The evidence of moral hazard is particularly found among small banks.
\end{abstract}

Keywords: banking; credit market; deposit insurance; deposit market; laboratory experiment; moral hazard

JEL classification: G21, G28

* Corresponding author's e-mail: gasahadewo@ugm.ac.id 


\section{Introduction}

A deposit insurance scheme is an essential component of a financial system safety net in an economy. Thus, many governments have implemented either an implicit or explicit deposit insurance scheme (Demirgüç-kunt et al. 2008; DemirgüçKunt et al. 2014; García 1999). The implementation of a deposit insurance scheme, however, entails a trade-off. On the one hand, a deposit insurance scheme reduces risk premium, the likelihood of a bank run or a bank crisis. The effects of a deposit insurance scheme have been shown theoretically and empirically by McCoy (2006), Schotter and Yorulmazer (2009), Janoss Kiss et al. (2011), Diamond and Dybvig (1983), Anginer et al. (2014), Barth et al. (2004) and Bartholdy et al. (2003).

On the other hand, a deposit insurance scheme may induce moral hazard among bankers (McCoy 2006; Chernykh and Cole 2011; Grossman 1992; Ioannidou and Penas 2010; Keeley 1990). The insurance incentivises bankers to increase leverage by offering a higher deposit rate to depositors. As a result, the bank needs to increase the loan interest rate. Borrowers that take a higher interest rate are the ones with riskier projects. This process increases the risk of the bank's asset portfolio. If such a process occurred system-wide, a deposit insurance scheme might lead to a bank failure (Demirgüç-Kunt and Detragiache 2002)

As far as the researchers are aware, whether or not a deposit insurance scheme and the size of its coverage induces moral hazard among bankers have not been tested rigorously. Using an experimental setting, the researchers contribute to the literature by testing the effects of deposit insurance schemes on bankers' behaviours particu- larly in offering a deposit rate and choosing projects. This study also tests whether bankers' choices differ when they have to pay a fixed insurance premium in comparison to when they have to pay a risk-based premium.

This study achieved this by designing and conducting a laboratory experiment in which the decision-making environment was motivated by the setting of the deposit insurance scheme in Indonesia. The experiment consists of two markets: the deposit market and the credit market. Within these markets, three banks compete to attract funds and to channel them as credits. One of the banks has a large initial asset, while the other two banks have smaller primary assets and such a composition reflects the fact that, in Indonesia, the number of small banks significantly exceeds the number of large banks.

This study found that increasing the coverage limit does not affect bankers' deposit rate offers. These findings explain that bankers tend to compete to attract all funds available in the market irrespective of the coverage limit. The existence of a deposit insurance scheme, however, significantly reduces the likelihood of bankers offering a deposit rate higher than the threshold rate. This implies that a deposit insurance scheme is essential in keeping the costs of funds low. This study also found that big banks are more likely to offer a deposit rate above the threshold rate than the small banks. By doing so, the big banks have a higher probability of attracting funds from the depositors and keeping the costs of funds low. The researchers' findings about the credit market suggest that a deposit insurance scheme with a high coverage limit induces moral hazard among small banks. 
This study contributes to several strands of literature regarding deposit insurance schemes. The first strand of the literature includes experimental studies that investigate the impact of a deposit insurance scheme on depositors' behaviours. The first experimental study in this literature shows that an implementation of a full-coverage insurance scheme prevents bank panics (Madiès 2006). A follow-up study investigates the effect of alternative insurance coverages and their interaction with the observability of depositors' choices. This study found that an insurance scheme with either full or partial coverage reduces bank failure if depositors' choices were observed. Moreover, an insurance scheme with full coverage reduces bank failure even if depositors' choices are not observed (Janoss Kiss et al. 2011). A more recent study found that uncertainty about the size of a partialcoverage insurance scheme increases the likelihood of a bank run (Peia and Vranceanu 2017).

The second strand of literature includes studies that use observational data to investigate the effects of a deposit insurance scheme on various outcomes in the banking sector. Using a sample of developing and developed countries between 1980 and 1994, one study found that a deposit insurance scheme is negatively correlated with bank stability (Demirgüç-Kunt and Detragiache 2002). Another study that uses cross-country panel data between 1980 and 2004 also finds an effect of a deposit insurance scheme on bank insolvency and bank runs (Ngalawa et al. 2016). A similar study also shows that the implementation of a deposit insurance scheme increases the likelihood of bank failure (Hooks and Robinson 2002), loan-deposit rate spread
(Carapella and Giorgio 2004), and moral hazard (Yilmaz and Muslumov 2008).

The main issue seen in these findings is the identification of the effect of the deposit insurance scheme on the outcomes of interests. First, changes in outcomes over time cannot be attributed only to the introduction of or changes to a deposit insurance system but also to changes in other variables that were not observed in the estimation model. Second, these studies face the issue of reverse causality or simultaneity bias. For example, an implementation of a high coverage limit in the deposit insurance system may increase risk-taking behaviours among banks. As a response to these behaviours, the agency increases the coverage limit to maintain the confidence of the market. It is difficult, therefore, to isolate the effect of the deposit insurance scheme on behaviours. This study contributes to this literature by providing a rigorous identification of the deposit insurance effect using an experimental method.

The third strand of literature includes studies that discuss components of a deposit insurance scheme that may reduce moral hazard. A component that may induce depositors' oversight of a bank's behaviours is the coverage limit. The limit imposes the amount of deposit that will be insured by the system in cases of bank failure (García 1999). Another component that may be integrated into a deposit insurance scheme is the differential premium, which differentiates insurance premiums based on the risks of a bank's asset portfolio. Thus, a bank with a riskier asset portfolio pays a higher premium. The implementation of a differential premium may incentivise banks to manage and to reduce the risk of their asset portfolio. As of 2013, 35 countries 
have implemented the differential premium (Demirgüç-Kunt et al. 2015). The effect of a differential premium on banking behaviours, however, is not known. This study contributes to this literature by providing empirical evidence on the effect of a differential premium on banking behaviours.

Lastly, this study provides essential policy insights for the design of the Indonesian Deposit Insurance System. The Indonesian banking system consists of 116 conventional banks and more than 1,600 rural banks. These banks are facing stiff competition in acquiring deposit funds and in channelling the funds to the credit market. Moreover, many rural banks are not well managed. As a result, almost all of the 83 banks liquidated by the Indonesian Deposit Insurance Corporation since its establishment in 2004, were rural banks. There is a concern that the current deposit insurance coverage of IDR2 billion (US\$13,793) induces moral hazard among rural banks. ${ }^{1}$ Indeed, this study provides an insight that high deposit insurance coverage may induce risk-taking behaviours among small banks.

\section{Experimental Design}

The primary objective of this study is to investigate the effects of a deposit insurance scheme on moral hazard among bankers using an experimental method. The primary outcomes of interest in the experiment are banks' deposit rate offers and choices of projects. Therefore, the researchers desiged a decision-making experiment with two distinct markets: the deposit market (Stage 1) and the credit market
(Stage 2). As an overview, banks collect funds in the deposit market and channel the collected funds to finance projects in the credit market. The completion of projects and realizations of projects' outcomes indicates the end of a particular round.

\section{The Deposit Market}

There are three players in the experiment: bankers, depositors, and debtors. Participants play the role of bankers, while computers play the roles of depositors and debtors. The decision to use computerised depositors and debtors is entirely a design choice. First, the main focus of the experiment is to investigate bankers' behaviours. Second, the costs for having participants playing the role of depositors and debtors would be quite high. Third, participants, if they were to play the role of depositors and debtors, would have much idle time after they made decisions. The downside of this design choice is that depositors and debtors are entirely rational because they choose banks only based on interest rates.

The roles of banks in the experiment are to negotiate a deposit rate with depositors in the deposit market and to negotiate a credit rate with debtors in the credit market. The setting in Indonesia motivates the composition of banks in the market and banks' functions. Specifically, there are three banks in the market: a bank with a large asset (henceforth, a big bank) and two banks with smaller but equal assets (henceforth, small banks). Each participant plays a particular role for the entire experimental sessions. The big bank may channel depositors' funds to finance projects (inter-

\footnotetext{
${ }^{1}$ This figure is based on exchange rate in end of July whereby US\$1 is equivalent to IDR14,500
} 
mediary financial function) or to purchase risk-free assets that provide a fixed return of 6 percent (non-financial intermediary function). On the other hand, the small banks can only channel depositors' funds to finance projects.

There are 10 depositors played by computers in the deposit market. Each depositor has a different amount of funds and reserve deposit rates. In Table 1 , researchers summarise the depositors' funds and reserve deposit rate. The depositors' reserve deposit rate is known to the depositors, but not the banks. This study design the depositor composition to be as close as possible to the actual composition in the Indonesian deposit market.

\section{Table 1.Depositors' Funds and Reserva- tion Deposit Rate}

\begin{tabular}{lccc}
\hline & Deposit & \multicolumn{2}{c}{$\begin{array}{c}\text { Reservation } \\
\text { Deposit Rate }\end{array}$} \\
\cline { 3 - 4 } Depositor & $\begin{array}{c}\text { Funds } \\
\text { (points) }\end{array}$ & $\begin{array}{c}\text { Big } \\
\text { Bank }\end{array}$ & $\begin{array}{c}\text { Small } \\
\text { Banks }\end{array}$ \\
\hline 1 & 50 & 4.00 & 6.00 \\
2 & 50 & 4.00 & 6.00 \\
3 & 50 & 4.00 & 6.00 \\
4 & 75 & 4.50 & 6.50 \\
5 & 75 & 4.50 & 6.50 \\
6 & 150 & 4.75 & 6.25 \\
7 & 300 & 5.00 & 7.00 \\
8 & 600 & 5.25 & 7.25 \\
9 & 1,250 & 5.50 & 7.50 \\
10 & 2,500 & 5.75 & 7.75 \\
\hline $\begin{array}{l}\text { Total funds } \\
\text { in the deposit }\end{array}$ & 5,100 & & \\
market & & & \\
\hline
\end{tabular}

Note that the reserve deposit rates are a function of the amount of funds and the size of the bank. Specifically, a depositor with a larger fund has a higher reserve deposit rate. For each depositor, this study assumed that the reserve deposit rate for the big bank is smaller than that of the rate for small banks with a fixed margin of 200 basis points $(2 \%)$. This study based this assumption on the average difference in interest rates between small and big banks which is about $200-250$ basis points. The depositors, however, view the two rates as equivalent, e.g. depositor 5 is indifferent between a 5.00 percent deposit rate offered by the big bank and a 7.00 percent deposit rate offered by the small banks. This equality depicts non-pecuniary benefits that actual depositors enjoy from big banks such as the availability of online services, a more extensive ATM network, interoperability, and interconnectedness.

The depositor's decision rule is to choose a bank that offered a deposit rate above her reserve deposit rate. If more than one bank offered deposit rates above the reserve rate, then the depositor chooses a bank that offered the highest deposit rate considering the 2 percent fixed margin. For example, suppose that the big bank offered Depositor 14.25 percent while one of the small banks offered her 6.00 percent. Depositor 1 will choose the big bank because the offered deposit rate is equal to 6.25 percent if offered by a small bank.

For the experiment, this study designed a deposit insurance scheme featuring a coverage limit, a deposit rate threshold, and an insurance premium. These features are similar to the those set by the Indonesian Deposit Insurance Corporation (IDIC) for the current deposit insurance 
scheme. It is important to note that the big bank and the small banks are subject to different deposit rate thresholds. During the design phase in November 2017, the actual threshold deposit rates set by the IDIC were 5.75 percent for big banks and 8.75 percent for small banks. For the researchers experiment, also in this study set a threshold deposit rate for large banks to be 6 percent, while for small banks it becomes 8 percent.

The bank is obligated to return each depositor's deposit plus interest at the end of the round. The interest that banks must pay to each depositor based on the deposit rate agreed in the deposit market. For ex- ample, suppose that a bank collected 75 points from Depositor 4 with a deposit rate of 5 percent. The end of the round, the bank must return the 75 points plus 3.75 interests to Depositor 4.

Finally, a bank must pay a deposit insurance premium to the experimenter. The premium is proportional to the funds collected from the deposit market. In the baseline treatment, banks must pay a fixed 3 percent premium. In the differential premium treatment, a bank premium determined by its asset portfolio. Banks holding a riskier asset portfolio must pay a higher premium. The calculation of riskbased premium will be discussed in the next

Table 2. Firms' Capital Requirement, Probability of Success, and Maximum Credit Rate

\begin{tabular}{ccccccc}
\hline Firm & $\begin{array}{c}\text { Capital } \\
\text { Requirement }\end{array}$ & $\begin{array}{c}\text { Probability } \\
\text { of success } \\
(\%)\end{array}$ & $\begin{array}{c}\text { Maximum } \\
\text { Credit } \\
\text { Rate }(\%)\end{array}$ & $\begin{array}{c}\text { Expected } \\
\text { Gain }\end{array}$ & $\begin{array}{c}\text { Expected Loss } \\
(\text { RR=90\%) }\end{array}$ & $\begin{array}{c}\text { Expected Net Gain }= \\
\text { Expected Gain - } \\
\text { Expected Loss }\end{array}$ \\
\hline 1 & 250 & 50 & 25 & 31,25 & 12,5 & 18,75 \\
2 & 250 & 50 & 25 & 31,25 & 12,5 & 18,75 \\
3 & 250 & 50 & 25 & 31,25 & 12,5 & 18,75 \\
4 & 250 & 50 & 25 & 31,25 & 12,5 & 18,75 \\
5 & 500 & 50 & 22 & 55 & 25 & 30 \\
6 & 500 & 50 & 22 & 55 & 25 & 30 \\
7 & 250 & 70 & 14 & 24,5 & 7,5 & 17 \\
8 & 250 & 70 & 14 & 24,5 & 7,5 & 17 \\
9 & 500 & 70 & 10 & 35 & 15 & 20 \\
10 & 500 & 70 & 10 & 35 & 15 & 20 \\
11 & 250 & 80 & 10 & 20 & 5 & 15 \\
12 & 250 & 80 & 10 & 20 & 5 & 15 \\
13 & 500 & 80 & 9 & 36 & 10 & 26 \\
14 & 500 & 80 & 9 & 36 & 10 & 26 \\
\hline Total & 5.000 & & & & & \\
\hline
\end{tabular}


subsection. Note that the premium in the real economy is quite small at less than 1 percent. In this study, a higher premium was set in the experiment so that the presence of the deposit insurance is salient.

During a particular round in the experiment, the deposit market opens for four transaction phases. Each phase lasts for 180 seconds, and bankers can offer a deposit rate to depositors within the allocated time. Note that banks do not know the reserve deposit rate of each depositor. Thus, depositors can either reject or accept a bank's offer according to the decision rule. In the subsequent phases, banks can offer deposit rate to the remaining depositors.

\section{The Credit Market}

Banks channel funds collected in the deposit market to finance projects in the credit market. Banks can choose to finance projects from 14 firms, each with different capital requirements, project risk, and a maximum credit rate they can bear. The researchers summarised the firms in the credit market in Table 2. In general, the projects can be divided into three risk categories: a high-risk project, a medium-risk project, and a low-risk project. A high-risk project has only a 50 percent chance of success, while medium and low-risk projects have 70 and 80 percent chance of success, respectively.

Firms also have different preferences regarding the maximum credit rate, which is increasing with risk. Given the same capital requirement, firms with a high-risk project are willing to pay a higher credit rate than firms with medium or low-risk projects. For example, Firm 1 is willing to accept a credit rate of up to 25 percent while
Firm 7 is willing to accept a credit rate of up to 14 percent.

Banks that finance a successful project will receive the funds that were invested plus interest. For example, suppose that a bank finances Firm 1 with a credit rate of 25 percent and the firm's project is successful. The bank will receive the 250 capital plus interest of 62.5. On the other hand, suppose Firm 1's project fails. The bank will receive 90 percent, which is the recovery rate, of total capital invested. In this example, the recovery rate is 225 .

Overall, the expected gain of investing in each of the projects exceeds the expected loss. Thus, the expected net gain of each project is positive. Note, however, that there are variations in the expected net gains across projects that depend on the risk and the capital requirement. First, the expected net gains for high-risk projects are higher than the gains for medium or lowrisk projects given the same capital requirement. This variation incentivises banks to finance high-risk projects. Second, the expected net gains increase with the capital requirement given the same risk profile. This variation incentivises banks to finance projects with a higher capital requirement.

This study should note that banks, especially the big bank, have an option not to channel the funds to finance a project. As mentioned in an earlier paragraph, the big bank's remaining funds that are not channelled to finance a project will be invested automatically in a risk-free instrument that provides a fixed 6 percent return. This setting is designed based on the banking system in Indonesia. It is also important to highlight that the total funds available in the market are 5,100 points, which is slightly larger than the total fund needed 
to fund all projects. The relatively small excess supply of funds ensures the banks have some latitude in channelling the funds to the projects.

Similar to the deposit market, the credit market opens for four transaction phases. Each phase lasts for 180 seconds, and banks may offer a credit rate to firms within the allocated time. Banks do not know the maximum credit rate threshold of each depositor. The creditors, therefore, may either reject or accept a bank's offer according to the decision rule. In the subsequent phases, banks may offer credit rate to the remaining firms whose projects are not financed.

\section{Differential Premium}

In the baseline treatment, banks pay a fixed 3 percent premium to the experimenter. In the differential premium treatment, however, a bank pays a differential premium that depends on the risk profile of its asset portfolio. A bank with a riskier portfolio pays a higher premium.

This study used the following procedure to determine company premiums: first, weigh project capital requirements

\section{Table 3. Project Index Based on Its risk}

\begin{tabular}{lccc}
\hline Nominal Probability (\%) & $\begin{array}{c}\text { Weighted } \\
\text { Capital } \\
\text { Requirement }\end{array}$ & $\begin{array}{c}\text { Project } \\
\text { Index }\end{array}$ \\
\hline 250 & 50 & 250 & 1 \\
500 & 50 & 500 & 1 \\
250 & 70 & 350 & 1.4 \\
500 & 70 & 700 & 1.4 \\
250 & 80 & 400 & 1.6 \\
500 & 80 & 800 & 1.6 \\
\hline
\end{tabular}

with a relative probability of success; second, calculate the project index which is the ratio between weighted capital requirements and capital requirements.

The formula in this study implies that the probability of success, but not the capital requirement, determines a project's index. As shown in Table 3, projects with the same success probability have the same index irrespective of their capital requirement, and then the project index was used to calculate a bank's risk index. The formula to calculate a bank's risk index is

$$
\text { Risk Index }=\frac{\sum \text { Capital } x \text { Project Index }}{\Sigma \text { Capital }} .
$$

For instance, a bank finances a 250point project with a success probability of 50 percent and a 500-point project with a success probability of 70 percent. The risk index for the bank is 1.27. A bank's risk index determines the premium that a bank has to pay. Specifically, a bank must pay a premium of 5 percent if the risk index is strictly lower than 1.4 , of 3 percent if the risk index is higher than or equal to 1.4 and is lower than or equal to 1.6, of 1 percent if the risk index is strictly higher than 1.6.

\section{Treatment Design}

This study used a combination of within-subject and between-subject designs in this experiment and summarised the treatment design in Table 4. For the withinsubject treatment, researchers fix the deposit insurance scheme and vary the coverage limit. To avoid a sequence effect, the researchers varied the sequence of the coverage limit in different sessions. For example, in the first session, the sequence 
Table 4. Treatment Design

\begin{tabular}{|c|c|c|c|c|}
\hline $\begin{array}{l}\text { Deposit } \\
\text { Insurance } \\
\text { Scheme }\end{array}$ & & \multicolumn{3}{|c|}{$\begin{array}{l}\text { Coverage Limit } \\
\text { (within Subjects) }\end{array}$} \\
\hline $\begin{array}{l}\text { Baseline: } \\
\text { coverage limit }+ \text { deposit rate threshold }+ \\
\text { a fixed } 3 \% \text { insurance premium }\end{array}$ & $\begin{array}{l}\text { High } \\
(2,000)\end{array}$ & $\begin{array}{l}\text { Medium } \\
(1,000)\end{array}$ & $\begin{array}{l}\text { Low } \\
(500)\end{array}$ & $\begin{array}{c}\text { No } \\
\text { deposit } \\
\text { insurance }\end{array}$ \\
\hline $\begin{array}{l}\text { Treatment: } \\
\text { coverage limit }+ \text { deposit rate threshold }+ \\
\text { risk-based insurance premium }\end{array}$ & $\begin{array}{l}\text { High } \\
(2,000)\end{array}$ & $\begin{array}{l}\text { Medium } \\
(1,000)\end{array}$ & $\begin{array}{l}\text { Low } \\
(500)\end{array}$ & $\begin{array}{c}\text { No } \\
\text { deposit } \\
\text { insurance }\end{array}$ \\
\hline
\end{tabular}

starts from the highest coverage limit and ends with the no deposit insurance treatment. In the second session, the sequence starts from the no deposit insurance treatment and ends with the highest coverage limit.

This study used the combination of within-subjects and between-subjects designs in this experiment; the treatment design is summarised in Table 4. For the within-subject treatment, researchers fix the deposit insurance scheme and vary the coverage limit. To avoid a sequence effect, researchers vary the sequence of the coverage limit in different sessions. For example, in the first session, the sequence starts from the highest coverage limit and ends with the no deposit insurance treatment. In the second session, the sequence starts from the no deposit insurance treatment and ends with the highest coverage limit

This study used the between-subjects design to test the effect of a risk-based insurance premium on banks' behaviours. In the baseline session, a bank pays an insurance premium which is 3 percent of the total deposit it collected from the deposit market. In the treatment session, a bank pays an insurance premium that increases with the risk profile of its asset portfolio.

\section{Payoffs}

One experimental session consisted of four rounds in which the deposit insurance scheme is fixed while the coverage limit varies. The researchers randomly chose 1 out of 4 rounds for a payment round; and used such a design to induce participants to make decisions optimally in each round. The design could also minimise an income or portfolio effect as well as hedging behaviour. This study also randomised the chosen payment round across experimental sessions.

The payoffs for the big bank are the sum of primary assets, returns from successful projects, returns from unsuccessful projects, and unchanneled funds plus their interest, which are then the amount of deposit returned to depositors, and the premium payment deducted. The payoffs for the small banks are similar although they do not obtain interest from the unchanneled funds. The total payoffs from the chosen payment round were converted to Indonesian rupiah with a conversation rate of IDR1,000 for every 1 point of payoff.

A bank fails if the payoff is negative at the end of the round. This implies that the bank's revenue from interest cannot cover the bank's obligations such as deposit 
interest payment and insurance premium. Note that the experimenter insures depositors' funds when a bank fails in the case of non-negative insurance treatment (high, medium, and low coverage limit treatment). Thus, the failed bank receives zero points. On the other hand, in the case of no insurance treatment, the bank's negative payoff is erased at the payment counter. This study erases the negative payoff in a surprising manner and, more importantly, in private. $^{2}$

\section{Participants}

The researchers collaborated with the Indonesian Deposit Insurance Corporation to recruit managerial-level bankers into the subject pool. These bankers work in conventional banks, both state-owned and private banks, as well as rural banks in Yogyakarta, and did so by sending an invitation letter and a leaflet containing general information about incentivised decisionmaking games in a computer laboratory. This study did not mention or explain the study's investment game in the invitation or in the leaflet.

The decision to invite bankers as participants is mainly a design choice, first, to investigate whether a deposit insurance scheme affect bankers' behaviours or not, it is important to involve individuals expe-

Table 5. The Effects of Coverage Limit and Differential Premium Treatments on Adjusted Deposit Rate

\begin{tabular}{lccc}
\hline \multicolumn{1}{c}{$\begin{array}{c}\text { Dependent Variable: } \\
\text { Adjusted Deposit Rate Offer }\end{array}$} & $\begin{array}{c}\text { A: } \\
\text { Small Banks }\end{array}$ & $\begin{array}{c}\text { B: } \\
\text { Big Banks }\end{array}$ & $\begin{array}{c}\text { C: } \\
\text { All }\end{array}$ \\
\hline \multirow{2}{*}{ If Differential Premium Treatment } & $\begin{array}{c}0.57^{* * * *} \\
(0.20)\end{array}$ & $\begin{array}{c}0.26 \\
(0.34)\end{array}$ & $\begin{array}{c}0.42^{* *} \\
(0.18)\end{array}$ \\
& -0.15 & -0.35 & $-0.23^{*}$ \\
2,000 Coverage Limits & $(0.14)$ & $(0.23)$ & $(0.13)$ \\
& -0.14 & -0.057 & -0.098 \\
500 Coverage Limits & $(0.15)$ & $(0.20)$ & $(0.12)$ \\
& -0.12 & -0.041 & -0.096 \\
No Coverage Limit & $(0.17)$ & $(0.32)$ & $(0.17)$ \\
& & & $0.52^{* * * *}$ \\
1 If Big Bank & & & $(0.19)$ \\
\hline \multirow{2}{*}{ Observations } & 923 & 605 & 1,528 \\
Pseudo R-sq & 0.38 & 0.22 & 0.30 \\
\hline
\end{tabular}

Source: authors' calculations from primary data

Note: estimated coefficients excluded from the table are dummies for transaction phases, and a dummy for sequence. The notations $*$, $* *, * * *$ indicate significance at $10 \%, 5 \%$, and $1 \%$ level, respectively. Standard errors are clustered at the individual level.

\footnotetext{
${ }^{2}$ We discuss materials, procedures, and participants in an online appendix that can be accessed through the following link: https://www.dropbox.com/s/uz9d59x8rfn98eq/onlineappendix.docx?dl=0.
} 
rienced in the banking sector. Indeed, student participants usually recommended in experimental economics. However, students are not experienced in making decisions in the banking sector.

This study obtains a subject pool of 120 bankers and randomises them into four experimental sessions. Thus, each experimental session consists of 30 bankers. The participants were then randomly assigned to a group of three. Within each group, a participant was randomly assigned the role of the big bank, and the other two were the small banks. Several invitees did not show up in several experimental sessions. Therefore, the number of participants was below 30 in these sessions. For example, the number of participants in Session 2 and 3 was 27 , while the number of participants in Session 4 was 24.

Note that the staff from a particular bank cannot attend the same experimental sessions. This study emphasise to the bankers that their identities are made anonymous during the entire experiment, and furthermore, emphasise that the results will be reported in aggregate but not individually, and will not share individual banker's results to their employers.

Table 5 presents a statistical summary of the participants' characteristics. The share of female bankers was quite high in session 1 and session 3. Previous studies show that female bankers are more riskaverse than male bankers (Byrnes et al. 1999; Eckel and Grossman 2008a; Eckel and Grossman 2008b). Indeed, using the post-experiment survey data, the researchers found that female bankers have a lower risk preference index than male bankers (diff. -0.306, p-value 0.0000). The implies that gender composition needs to be controlled for throughout the session. The average age of bankers in the sample is 40.8 years, reflecting the fact that they are managerial level bankers.

\section{Results}

\section{Deposit Market}

This study first summarises basic statistics on small and big banks' decisions in the deposit market. ${ }^{3}$ On average, the small banks offered a deposit rate of 7.54 while the big banks offered a deposit rate of 6.02 (difference 1.52, p-value 0.000). These statistics imply that the costs of funds for the small banks were more significant than the costs of funds for the big banks. Thus, the small banks might have had to invest in firms that were willing to accept higher credit rate.

Bear in mind that depositors have different reserve deposit rates for big and small banks. To accommodate variations in reserve deposit rates, the researchers calculated the difference between the offer of bank deposit interest rates and depositors' deposit interest rates. This study refers to the adjusted deposit rate offer. By contrast, the big banks offered higher adjusted deposit rates to depositors. On average, the big banks offered a margin of 1.28 above depositors' reserve deposit rates, while the small banks offered a margin of 0.88 . This implies that the big banks were able to acquire more substantial amounts of funds from the deposit market. Indeed, on average, the big banks acquired 2,703 points

\footnotetext{
${ }^{3}$ The experimental data is available for replication upon request.
} 
from the deposit market, while the small banks acquired 1,961.

The researchers analyzed the effects of different deposit insurance schemes on banks' deposit offers. Specifically, the researchers regressed the adjusted rate offer on dummies for the coverage limit treatments and a dummy for the differential premium treatment are rejected, including dummies for the transaction phases to control for the phase effect and a dummy that indicates the type of the bank. Let $I$ indicate participant, $p$ indicates the premium treatment, $s$ indicates the coverage limit treatment, and $t$ indicates the phase. The regression model is:

$$
\begin{aligned}
\operatorname{adjrate}_{i p s t}= & \alpha+\beta \text { premium }_{p}+\delta \text { coverage } \\
& +\eta \text { big }_{i}+\gamma X_{s t}+a_{i}+\varepsilon_{i p s t} \ldots \ldots . . .
\end{aligned}
$$

where premium is a dummy with a value of 1 to indicate differential treatment, cov- erage is a vector of dummies for the coverage limit, big is a dummy with a value of 1 to indicate the big bank, $X$ is a vector of dummies for the transaction phases and a dummy for sequence, $a$ indicates participant-specific unobserved characteristics, and $\varepsilon$ indicates idiosyncratic errors.

Note that the adjusted deposit rate offer is bounded below at 0 . This study used the Tobit regression model to accommodate the corner solution. Note that the implementation of the differential premium treatment in a random manner should be uncorrelated with individual characteristics a. Thus, this study did not include participant-level fixed effects in the regression model. Lastly, this study cluster the standard errors at the individual level to accommodate the within-subject design that implemented. Table 6 presents the results of the regression.

\section{Table 6. The Effects of Coverage Limit and Differential Rate Treatments on Credit Rate Offer}

\begin{tabular}{llll}
\hline $\begin{array}{c}\text { Dependent Variable: } \\
\text { Credit Rate Offer }\end{array}$ & $\begin{array}{c}\text { A: } \\
\text { Small Banks }\end{array}$ & $\begin{array}{c}\text { B: } \\
\text { Big Banks }\end{array}$ & $\begin{array}{c}\text { C: } \\
\text { All }\end{array}$ \\
\hline 1 If differential rate treatment & -0.30 & 0.84 & 0.087 \\
& $(0.79)$ & $(1.45)$ & $(0.80)$ \\
2,000 Coverage limits & $1.81^{* * * * *}$ & 1.05 & $1.43^{* *}$ \\
& $(0.62)$ & $(1.13)$ & $(0.63)$ \\
500 Coverage limits & 0.29 & 0.67 & 0.27 \\
& $(0.77)$ & $(0.78)$ & $(0.50)$ \\
No coverage limit & -0.093 & 0.42 & -0.11 \\
& $(0.73)$ & $(0.81)$ & $(0.54)$ \\
1 If big bank & & & $-2.95^{* * *}$ \\
& & & $(1.01)$ \\
\hline Observations & 861 & 656 & 1517 \\
Pseudo R-sq & 0.12 & 0.11 & 0.11 \\
\hline
\end{tabular}

Source: authors' calculations from primary data

Note: estimated coefficients excluded from the table are dummies for transaction phases, a dummy for capital requirement, and a dummy for sequence. The notations $*, * \%, * \%$ indicate significance at $10 \%, 5 \%$, and $1 \%$ level, respectively. Standard errors are clustered at the individual level. 
The results in Column $\mathrm{C}$ of Table 5 show that big banks offered higher deposit rates than small banks. These results are not entirely surprising, even after the deposit rates are adjusted, because big banks acquired more substantial amounts of funds from the deposit market. An average big bank acquired 2,703 points from the deposit market, while an average small bank acquired 1,961 points. Such behaviour can be driven by the fact that big banks have a larger amount of assets which can absorb project losses. Moreover, big banks can channel the acquired funds to assets with fixed returns, and this also helps the banks absorb projects' losses. These features of the big banks may eventually reduce the probability of banks' failure.

This study found no effect of increasing the coverage limit on deposit rate offers by the big and small banks. Big and small banks did not become more aggressive regarding offering deposit rates when the coverage limit changes. However, there is evidence that a higher coverage limit reduces the deposit rate offered by banks. The estimated effect seems to be bigger among big banks who are offering higher adjusted deposit rates in the market. However, the effect of the 2,000 coverage limit among all banks is only marginally significant. These findings imply that banks, whatever the coverage limit, competitively acquire the available funds in the deposit market, otherwise they cannot invest in the credit market.

However, this study found that the implementation of a differential premium treatment significantly affects banks' behaviours, particularly small banks. Specifically, small banks offered significantly higher deposit rates in the differential premium treatment than in the fixed premium treatment. The explanation is that the implementation of a differential premium treatment induces expectations among small banks that they will pay a higher premium if their asset portfolio is risky. Thus, a differential premium justified a bank seeking riskier projects that accept higher interest rates. This study did not see this behaviour among the big banks because they can channel the collected funds to riskfree alternatives. On the other hand, small banks must finance riskier projects to obtain a profit margin because their costs of funds are already higher.

The researchers have run similar regressions to observe whether the coverage limit and the differential premium treatment affect banks' compliance on offering deposit rate below or equal to the threshold deposit rate. This study has presented the results in Table A3 of the online appendix and found consistent results with those presented in Table 5. The big banks are more likely to offer deposit rates above the threshold rate, which can be explained by the more substantial amounts of funds they acquired from the market. The differential premium treatment also significantly induces small banks to offer deposit rate above the threshold rate.

The researchers acknowledge that the results in this study may seem counterintuitive. An implementation of a differential premium can induce banks to reduce the risks of their asset portfolio. The design can induce banks' behaviours in this experiment. The only cost associated with a high-risk asset portfolio in this experiment is a higher premium that banks can pay in any case. In the real setting, the costs associated with a high-risk asset portfolio are more complicated than just a higher premium. It could also be the case that the 
higher the premium a bank pays, the more eager the bank is to engage in riskier decisions. The bank is merely optimizing the benefit of the deposit insurance.

\section{Credit Market}

In the credit market, banks channelled the acquired funds from the deposit market to finance firms' projects. This study first summarises the small and big banks' choices. On average, the big banks channelled more funds to the credit market because the acquired more funds from the . An average big bank channelled 3,312 points, while an average small bank channelled 2,540 points (difference -771, p-value 0.007).

The share of the small banks that funded risky projects is also higher than the share of big banks that funded risky projects, although the difference is not significant $(0.039$, p-value 0.136). Nevertheless, the fact that small banks are funding risky projects is reflected in the credit rate. Specifically, the average credit rate that small banks offered to firms is about 3 percent more than the average credit rate that big banks offered (p-value 0.000). The main explanation for this difference is that small banks, by design, have higher costs of funds.

This study now analyses the effects of different deposit insurance schemes on banks' credit rate offers. Specifically, the regressed credit rate offers on dummies for the coverage limit treatments and a dummy for the differential premium treatment was rejected. The use of a Tobit regression model, because the credit level is limited to below 0 and above 25 . With the included data for the transaction phase to control the phase and dummy effects that indicate the type of bank. Using the same notation as in the previous regression, the regression model is:

$$
\begin{aligned}
\text { Creditrate }_{i p s t} & =\alpha+\beta \text { premium }_{p}+\delta \text { coverage }_{s} \\
& +\eta \text { big }_{i}+\gamma X_{s t}+a_{i}+a i+\varepsilon_{i p s t}
\end{aligned}
$$

Where premium is a dummy with a value of 1 to show differential treatment, coverage is a vector of dummy for a coverage limit, big is a dummy with a value of 1 to indicate the big bank, $X$ is a vector of dummies for the transaction phases and a dummy for sequence, $a$ indicates participant-specific unobserved characteristics, and $\varepsilon$ indicates idiosyncratic errors. The regression results in Table 7 .

Consistent with the summary statistics, the average credit rate that big banks accepted is lower than the average credit rate that small banks accepted by about 3 percent. Again these findings imply that small banks have to finance higher-risk projects to obtain a margin from the high costs of funds. This study found no impact of the differential premium treatment on credit rate offer, even among small banks who were induced by the treatment to offer higher adjusted deposit rate. The main explanation for this finding is that small banks are already taking high-risk projects at high credit rate. Thus, the differential premium treatment does not induce small banks to offer higher credit rate.

Estimates from this study show that a high coverage limit treatment has a significant effect on credit rate offer. However, the effect is limited among small banks but not among big banks. On average, small banks offered a higher credit rate by almost 2 percent when the coverage limit is 2,000 . The differences in the average credit rates 
Table 7. The Effects of Coverage Limit and Differential Rate Treatments on Credit Rate Offer

\begin{tabular}{lccc}
\hline $\begin{array}{c}\text { Dependent Variable: } \\
\text { Credit Rate Offer }\end{array}$ & $\begin{array}{c}\text { A: } \\
\text { Small Banks }\end{array}$ & $\begin{array}{c}\text { B: } \\
\text { Big Banks }\end{array}$ & $\begin{array}{c}\text { C: } \\
\text { All }\end{array}$ \\
\hline 1 if differential rate treatment & -0.30 & 0.84 & 0.087 \\
& $(0.79)$ & $(1.45)$ & $(0.80)$ \\
2,000 coverage limits & $1.81^{* * * *}$ & 1.05 & $1.43^{* * *}$ \\
& $(0.62)$ & $(1.13)$ & $(0.63)$ \\
500 coverage limits & 0.29 & 0.67 & 0.27 \\
& $(0.77)$ & $(0.78)$ & $(0.50)$ \\
no coverage limit & -0.093 & 0.42 & -0.11 \\
& $(0.73)$ & $(0.81)$ & $(0.54)$ \\
1 if big bank & & & $-2.95^{* * * *}$ \\
& & & $(1.01)$ \\
Observations & 861 & 656 & 1517 \\
Pseudo R-sq & 0.12 & 0.11 & 0.11 \\
\hline
\end{tabular}

Source: authors' calculations from primary data

Note: estimated coefficients excluded from the table are dummies for transaction phases, a dummy for capital requirement, and a dummy for sequence. The notations $*, * *, * * *$ indicate significance at 10 percent, 5 percent, and 1 percent level, respectively. Standard errors are clustered at the individual level.

Figure 1. Average Credit Rate Across Coverage Limits

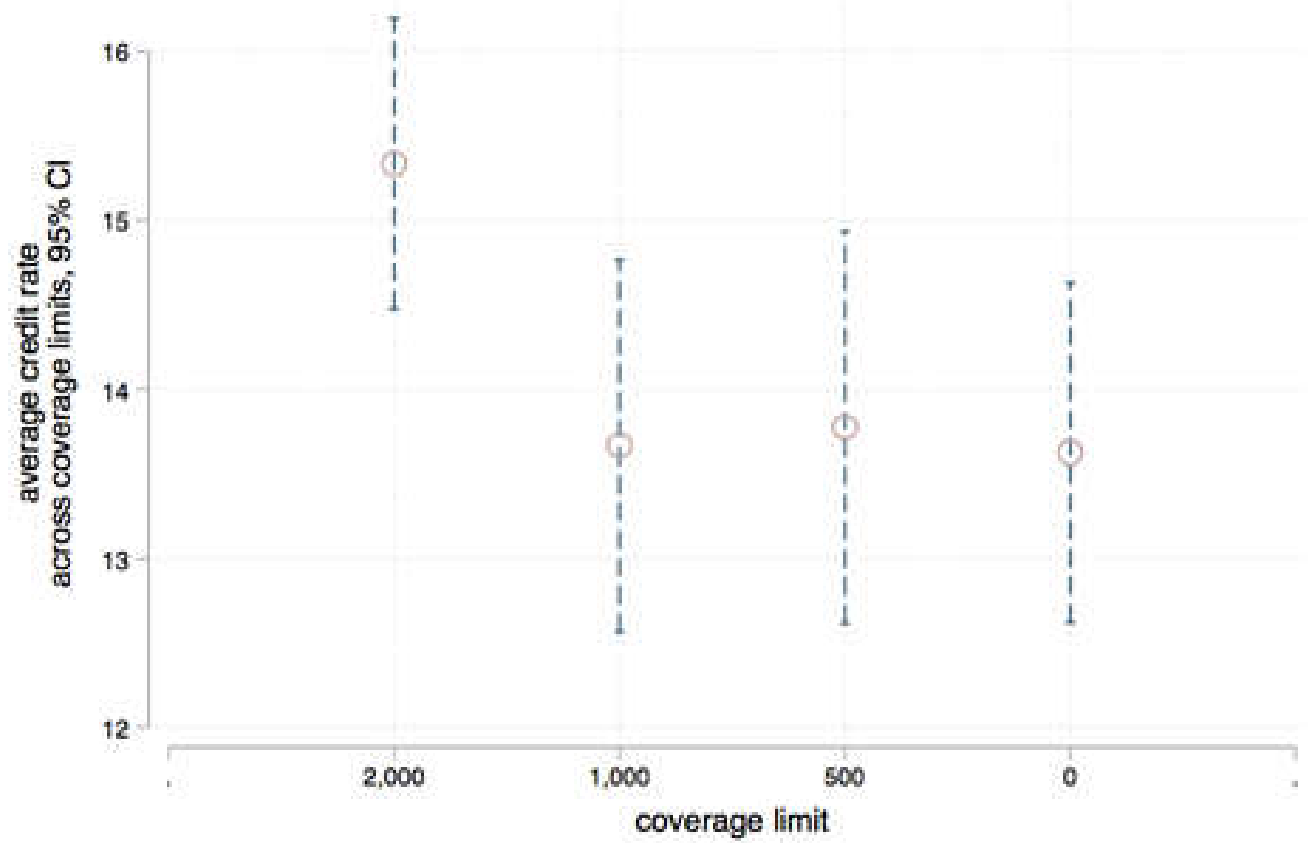


Sabadewo et al.

across coverage limits are depicted in Figure 1 , and it can be observed that the average credit rate when there is no deposit insurance or when the coverage limit was 500 or 1,000 does not differ significantly. In these treatments, the average credit rate is slightly below 13.8 percent, on the other hand, the average credit rate when the coverage limit was 2,000 is above 15.3 percent.

The main explanation for these findings is the relative share of risky projects regarding coverage limit treatment. In particular, the share of risky projects is higher when the coverage limit is high. For example, the share of risky projects among small banks when the coverage limit is 2,000 points is 50.45 percent, while the share of risky projects among them when the coverage limit is 1,000 points is 45.98 percent. Thus, the higher credit rate implies a higherrisk asset portfolio.

To summarise, this study found that big banks channelled more funds to the credit market than small banks because they obtain larger funds from the deposit market. The big banks channelled their funds to lower-risk projects, while the small banks channelled their funds to higher-risk projects. The differential premium treatment, although it affects small banks' behaviours in the deposit market, has no significant effect on credit rate offer. This study also found a significant effect of a high coverage limit on credit rate behaviours among small banks. Specifically, on average, small banks offered a higher credit rate when the coverage limit is 2,000. This behaviour is driven by the fact that small banks have a higher share of risky projects when the coverage limit is 2,000 .

\section{Conclusion}

This study designed an experiment to test the effects of a coverage limit and a differential premium treatment on bankers' behaviours in the deposit and credit market. The results of the experiment show that the coverage limit treatments do not have any effect on banks' deposit rate offers in the deposit market. The researchers found imply that banks compete to acquire funds from the deposit market whatever the coverage limit. However, the differential premium treatment increases the likelihood of small banks to offer deposit rate above the threshold rate. Consequently, the differential premium treatment induces small banks to offer higher deposit rate.

In the credit market, small banks are financing riskier projects that accept higher interest rates. They do so because they have a relatively higher cost of funds. This study found that the high coverage limit induces small banks to finance higher-risk projects at higher credit rate. These findings indicate that a higher coverage limit induces moral hazard among small banks.

The researchers note several caveats of these study that can be improved by future studies. First, bankers face rational depositors that only care about deposit rates when choosing banks. In reality, depositors care not only about the deposit rate but also services that a bank can offer. Thus, negotiations in the deposit market can be a more complex task.

Second, the depositors in the experiments are played by computers. Thus, bankers may not regret losing the depositors' funds so much compared to when bankers obtain the funds from real deposi- 
tors; and finally, the structure of the market is limited to just three banks of two different sizes. In reality, the number of small banks is considerably larger, and the competition to acquire funds from the deposit market and to channel the funds are more intense. Despite this, the study's design already captures the essential aspects of decision making within the banking industry.

This study discussed policy implications for the deposit insurance regulations in Indonesia and found no effect of the coverage limit treatment on the deposit rate. However, it is important for the Indonesian Deposit Insurance Corporation and the Indonesian Financial Supervisory Authority to strengthen the market conduct regulations. Some banks offer deposit rates above the threshold rate set by the Indonesian Deposit Insurance Corporation. The results of the experiment also show that a high coverage limit can induce moral hazard among small banks. The policy implication of this finding is that the Indonesian Deposit Insurance Corporation can decrease the current coverage limit. Such an action is feasible because depositors are becoming more informed and more rational in choosing banks. However, the decrease in the current coverage limit must be accompanied by tighter supervision and scrutiny of banks' market conduct.

A lower coverage limit may not be favorable for more than 1,600 rural banks (bank perkreditan rakyat) in Indonesia. The lower coverage limit may reduce depositors' incentives to deposit their funds in these banks, which manage riskier asset portfolios than the conventional banks.
The governing and supervision bodies can establish a roadmap that gives small or rural banks incentives to merge into bigger banks. Size does matter in the banking industry, and merging of rural or small banks into bigger banks increases economies of scale and improves the efficiency of their business. The governing and supervision bodies can also incentivise bigger or conventional banks to acquire small and rural banks to obtain better economies of scale. The system will consist of significantly less small banks and significantly more bigger and more efficient banks. That informed, the roadmap must keep the number and concentration of banks in balance to maintain the competitiveness and stability of the banking system. All in all, this roadmap aims to decrease the probability of a bank failure in the system. This would ultimately decrease the probability of a systemic failure.

Lastly, this study discussed the research implications for bank management. The findings of the researchers suggest that there is no significant effect of deposit insurance schemes on deposit rates. However, this study found that several banks offer deposit rates higher than the threshold rate, consistent with the empirical evidence. Therefore, bank management must strengthen their market conduct practices in the deposit market to be in line with the regulations. Bank management must also strengthen its supervision on bankers' choices of projects. The risk portfolio of chosen projects affects a bank's overall risk portfolio. 
Sabaderwo etal.

\section{Acknowledgement}

We thank Halim Alamsyah; Fauzi Ichsan; Destry Damayanti; Moch. Doddy Ariefianto; and Herman Saheruddin for their constructive feedbacks. We thank Giovani Van Empel; Arif Anindita; Naila Safira; Muhammad Ali Faiq for their outstanding assistance throughout the study.

Funding: This work was supported by the Indonesia Deposit Insurance Corporation (Lembaga Penjamin Simpanan)

\section{References}

Anginer, D., A. Demirguc-Kunt, and M. Zhu. 2014. How does deposit insurance affect bank risk? Evidence from the recent crisis. Journal of Banking and Finance.

Anginer, D., Demirguc-Kunt, A. and Zhu, M., 2014. How does deposit insurance affect bank risk? Evidence from the recent crisis. Journal of Banking and Finance.

Barth, James R., G. CaprioJr., R. Levine. 2004. Bank regulation and supervision: What works best? Journal of Financial Intermediation 13 (2): pp.205-248.

Bartholdy, J., G. W. Boyle, and R. D. Stover. 2003. Deposit insurance and the risk premium in bank deposit rates. Journal of Banking and Finance.

Carapella, F., and G. D. Giorgio. 2004. Deposit insurance, institutions, and bank interest rates. Transition Studies Review 11 (3): 77-92. Available at: https://doi.org/10.1007/s11300-0040006-z.

Chernykh, L., and R. A. Cole. 2011. Does deposit insurance improve financial intermediation? Evidence from the Russian experiment. Journal of Banking and Finance.

Demirgüç-Kunt, A., and E. Detragiache. 2002. Does deposit insurance increase banking system stability? An empirical investigation. Journal of monetary economics 49 (7): 1373-1406.

Demirgüç-kunt, A., E. Kane, and L. Laeven. 2008. Deposit insurance design and implementation: Policy lessons from research and practice. In Deposit Insurance Around the World: Issues of Design and Implementation: 481-490.

Demirgüç-Kunt, A., E. Kane, and L. Laeven. 2015. Deposit insurance around the world: A comprehensive analysis and database. Journal of Financial Stability.

Demirgüç-Kunt, A., E. Kane, and L. Laeven. 2014. Deposit insurance database. IMF Working Paper WP/14/118.

Diamond, D. W. and P. H. Dybvig. 1983. Bank runs, deposit insurance, and liquidity. Journal of Political Economy 91 (3): 401-419. Available at: https://www.jstor.org/stable/1837095 [Accessed November 17, 2016].

García, G., 1999. Deposit insurance: A survey of actual and best practices. Working Paper of the International monetary Fund.

Grossman, R. S. 1992. Deposit insurance, regulation, and moral hazard in the thrift industry: evidence from the 1930s. American Economic Review. 
Hooks, L. M., and K. J. Robinson. 2002. Deposit insurance and moral hazard: Evidence from Texas banking in the 1920s. Journal of Economic History.

Ioannidou, V. P. and M. F. Penas. 2010. Deposit insurance and bank risk-taking: Evidence from internal loan ratings. Journal of Financial Intermediation.

Janoss Kiss, H., I. Rodriguez-Lara, and A. Rosa-Garcia. 2011. On the Effects of Deposit Insurance and Observability on Bank Runs: An Experimental Study.

Keeley, M. C. 1990. Deposit insurance, risk, and market power in banking. The American Economic Review.

Madiès, P. 2006. An experimental exploration of self-fulfilling banking panics: Their occurrence, persistence, and prevention. The Journal of Business 79 (4): 1831-1866. Available at: https:// www.jstor.org/stable/10.1086/503650 [Accessed August 17, 2018].

McCoy, P.A. 2006. The Moral Hazard Implications of Deposit Insurance: Theory and Evidence.

Ngalawa, H., F. T. Tchana, and N. Viegi. 2016. Banking instability and deposit insurance: the role of moral hazard. Journal of Applied Economics.

Peia, O., and R. Vranceanu. 2017. Experimental Evidence on Bank Runs Under Partial Deposit Insurance. Available at: http://www.ssrn.com/abstract =2955171 [Accessed August 17, 2018].

Schotter, A., and T. Yorulmazer. 2009. On th dynamics and severity of bank runs: An experimental study. Journal of Financial Intermediation 18: 217-241. Available at: www.elsevier.com/ locate/jfi [Accessed November 16, 2016].

Yilmaz, E., and A. Muslumov. 2008. Deposit insurance and moral hazard problem: The case of Turkish banking system. Applied Economics. 
